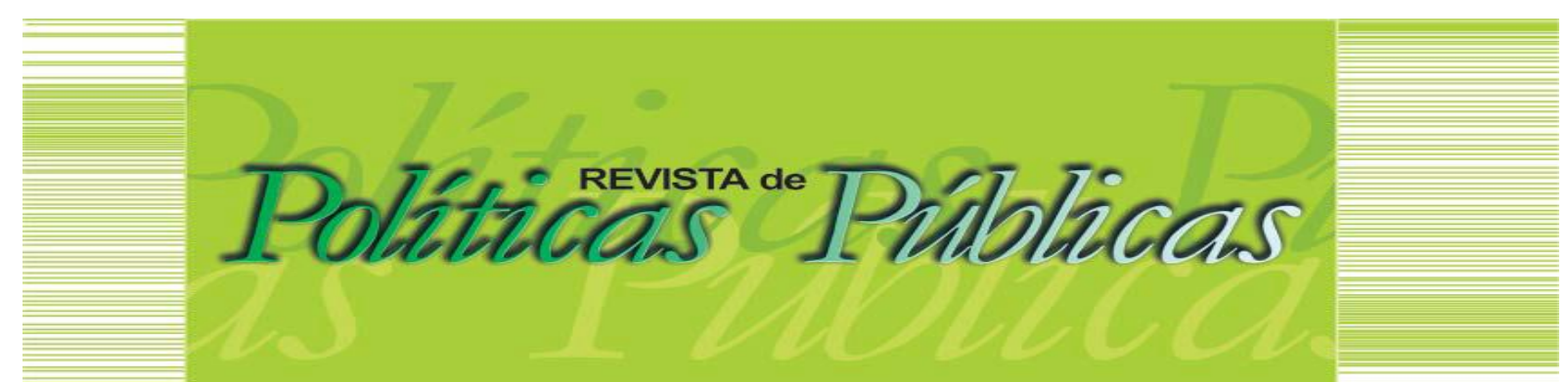

\title{
COULD MORE RESOURCES AND ACCESS IMPACT EFFICIENCY AND EFFECTIVENESS IN THE BRAZILIAN HEALTH MUNICIPALITIES?
}

\author{
Marco Antonio Catussi Paschoalotto 1 \\ João Luiz Passador² \\ Claudia Souza Passador ${ }^{3}$ \\ Pedro Henrique de Oliveira ${ }^{4}$
}

\begin{abstract}
The paper analyses the connection between resources, access, efficiency and effectiveness in 645 municipalities in the São Paulo State, Brazil, between 2009 and 2014. To achieve it, the essay has developed descriptive statistics, correlation analysis and principal component regression analysis. The descriptive statistics have shown high inequality in the health delivered services in resources, access and effectiveness. The correlation analysis has pointed out a possible financial dependence of the municipalities from the transferred funds. Finally, the regression analysis has demonstrated: a non-direct relation between resources and effectiveness in a public health system, a better capacity of the financial and human resources on explaining access and efficiency, and a higher impact of nurses in access and efficiency than physicians in the primary care.
\end{abstract}

Keywords: Public health. Health performance. National Health Service. Efficiency, Effectiveness.

\section{PODEM MAIS RECURSOS E ACESSO IMPACTAR A EFICIÊNCIA E A EFICÁCIA NOS MUNICÍPIOS DE SAÚDE DO BRASIL?}

\section{Resumo}

O artigo analisa a relação entre recursos, acesso, eficiência e eficácia em 645 municípios do Estado de São Paulo, Brasil, entre 2009 e 2014. Para tanto, o ensaio desenvolveu estatística descritiva, análise de correlação e análise de regressão de componentes principais. As estatísticas descritivas mostraram grande desigualdade nos serviços prestados de saúde em termos de recursos, acesso e eficácia. A análise de correlação apontou possível dependência financeira dos municípios dos recursos repassados. Finalmente, a análise de regressão demonstrou: uma relação não direta entre recursos e eficácia em um sistema público de saúde, uma melhor capacidade dos recursos financeiros e humanos em explicar o acesso e eficiência, e um maior impacto dos enfermeiros no acesso e eficiência do que os médicos na atenção primária.

Palavras- chave: Saúde Pública. Desempenho de saúde. Serviço Nacional de Saúde. Eficiência. Eficácia

Artigo recebido em: 05/05/2020 Aprovado em: 01/11/2020 DOI: http://dx.doi.org/10.18764/2178-2865.v24n2p619-633

${ }_{1}$ Graduado em Administração Pública. Doutor em Administração de Organizações pela Universidade de São Paulo. Professor do Departamento de Administração e Coordenador Geral da Pós-graduação Lato Sensu da Universidade do Oeste Paulista. E-mail: marcocatussi@gmail.com

2 Graduado em Administração. Doutor em Administração de Empresas pela Fundação Getúlio Vargas - SP. Professor Titular do Departamento de Administração da Faculdade de Economia Administração e Contabilidade de Ribeirão Preto da Universidade de São Paulo. E-mail: jlpassador@usp.br

3 Graduada em Ciências Sociais e Comunicação Social. Doutora em Educação pela Universidade de São Paulo.. Professora do Departamento de Administração da Faculdade de Economia, Administração e Contabilidade de Ribeirão Preto da Universidade de São Paulo. E-mail: cspassador@usp.br

${ }^{4}$ Graduado em Administração Pública. Mestre e Doutorando em Engenharia de Produção pela Escola de Engenharia de São Carlos da Universidade de São Paulo (EESC/USP) pela Faculdade de Ciências e Letras de Araraquara da Universidade Estadual Paulista. E-mail: oliveiraph1@gmail.com 


\section{INTRODUCTION}

The World Health Organization (WHO) (2018) debated the difficulty and importance of discussing the effectiveness of health delivered services. As well, the last report from the World Bank about the Brazilian National Health System (SUS) appointed as the necessity of improving the efficiency and effectiveness of health care services (World Bank, 2018).

One of the ways to improve the efficiency and effectiveness of these services is to increase the resources (human and financial) and access (CARRER; TOSO; GUIMARÃES; CONTERNO; MINOSSO, 2016; SANTOS; FRANCISCO; GONÇALVES, 2016; PASCHOALOTTO; PASSADOR; OLIVEIRA; LOPES, DANTAS; PASSADOR, 2018). Moreover, analyzing the relation between resources, access, efficiency and effectiveness have entered the public health agenda of scientific researchers (PALMER; MUELLER; GILSON; MILLS; HAINES, 2004).

According to Hjortdberg \& Mwikisa (2002), more financial resources can have different effects on health care access, because of the distances between the cities. Also, stopping the financing of human resources, or just through reducing your salaries, could negatively impact the access to some services in a health care system (MCPAKE et al., 2013).

The decrease of human resources to deliver health services has entered in crisis around the world, instigating much more the topics of efficiency and effectiveness (NARASIMHAN et al., 2004). All these points can be seen in a financial crisis, as happened in Europe, where some countries decreased expenditures in Public Health and increased the control of human resources, with finality to improve efficiency (CORREIA; DUSSAULT; PONTES, 2015).

On the other side, the discussion about increasing the access in public health has appeared in different countries with the aim of providing a better sustainable health care system with fewer resources (PENNESTRI, 2017). The Lago, Moscoso, Eugenia \& Ripari (2012) discusses the same point, although more resources were expended in different regions, the rates of child mortality and unsatisfied necessities did not decrease in all of them. Therefore, to provide a more accessible health care system is not enough to boost the expenditures, neither to develop new drugs, instead we should also pay attention in the efficiency and effectiveness of the delivered services (VODA; BOSTAN, 2018).

Being efficient has shown up as an important issue due to some financial crisis that have occurred in the world, such in Europe 2008/2009, which generated an unemployment boom and consequently necessity for public health services (MADUREIRA-LIMA; REEVES; CLAIR; STUCKLER, 2018). In China, after the health care reform in 2009 , despite the increasing in health expenditures, the efficiency did not follow the same standard, showing problems with governance structure in the Chinese health care system (WU; WANG; ZHANG, 2015). A case of success is the National Health Service in 
England, that has performed with efficiency on financial resources and high-quality on treatments of diseases (FRIEBEL, 2018).

But more important than improving the efficiency of resources or having a better access to health care, is forming an improved effectiveness multidisciplinary team to deliver public health services (SIMBA; MUKOSE; BAZEYO, 2014). The effectiveness can be affected by investments and resources expended through the health management and quantitative analysis (VERGUET; KIM; JAMISON, 2016).

In Brazil, the responsibility of executing the public health services are the municipalities, mainly the basic assistance, while medium and high complexity needs to involve the state and federal government (MENDES; CARNUT; GUERRA, 2018). Therefore, the health municipality indicators about performance are the most sensible to the primary conditions, in other words, the indicators related with basic attention health services (VIACAVA; UGÁ; PORTO; LAGUARDIA; MOREIRA, 2012; ALY; REIS, CARNEIRO; MORAES, 2017; ALBUQUERQUE; MARTINS, 2017).

Barros \& Lima (2015) and Ribeiro, Moreira, Ouverney, Pinto \& Silva (2018) pointed a big difference between the municipalities in Brazil among financial resources expended, human resources capacity, the effectiveness of the health care services and national coverage. At the same way, some regions and municipalities are being stratified into a more homogeneous group to apply resources and policies in public health (CALVO; LACERDA; COLUSSI; SCHNEIDER; ROCHA, 2016).

According to Barros \& Lima (2015), there is a financial dependence of the municipalities with resources coming from the SUS, which has an impact on the coverage and efficiency of the system. Meanwhile, financial dependence has decreased with more autonomy and own taxes collected by the municipalities (SANTOS; MENDES; PEREIRA; PARANHOS, 2017). Last, more financial resources in the municipalities can generate more chirurgical procedures, impairing some strategies from the WHO, as decreasing the number of cesarean births (PASCHOALOTTO et al., 2018).

Thus, in order to collaborate with the academic gap, our research question is "How resources and access could impact the efficiency and effectiveness in Public Health in the Brazilian municipalities?". To answer the question, we have analyzed the relationship between resources and access with efficiency and effectiveness in the municipalities, in the São Paulo State, Brazil. The hypotheses of this study are:

H1- More financial resources can provide more human resources in the Brazilian National Health System (SANTOS; FRANCISCO; GONÇALVES, 2016), H2- More financial and human resources can provide more access to the population in the Brazilian National Health System (SANTOS; FRANCISCO; GONÇALVES; PASCHOALOTTO et al., 2018), H3- More resources and access can provide more efficiency to the Brazilian National Health System (SANTOS; FRANCISCO; 
GONÇALVES, 2016; PASCHOALOTTO et al., 2018), H4- More resources, access and efficiency can provide more effectiveness to the Brazilian National Health System (CARRER et al., 2016; PASCHOALOTTO et al., 2018).

To deepen the discussion about the relations between the above dimension, we have elaborated sub-hypotheses: H5- There is a health inequality between the municipalities about financial resources, human resources, access, efficiency and effectiveness (CALVO et al., 2016; RIBEIRO et al., 2018), H6- The municipalities are dependents of the SUS's financial resources (Barros \& Lima, 2015), $\mathrm{H} 7-$ Municipalities with more financial resources tend to spend more money with medical procedures (PASCHOALOTTO et al., 2018).

The figure 1 shows the schematic relation between the hypothesis:

Figure 1 - Hypotheses Structure

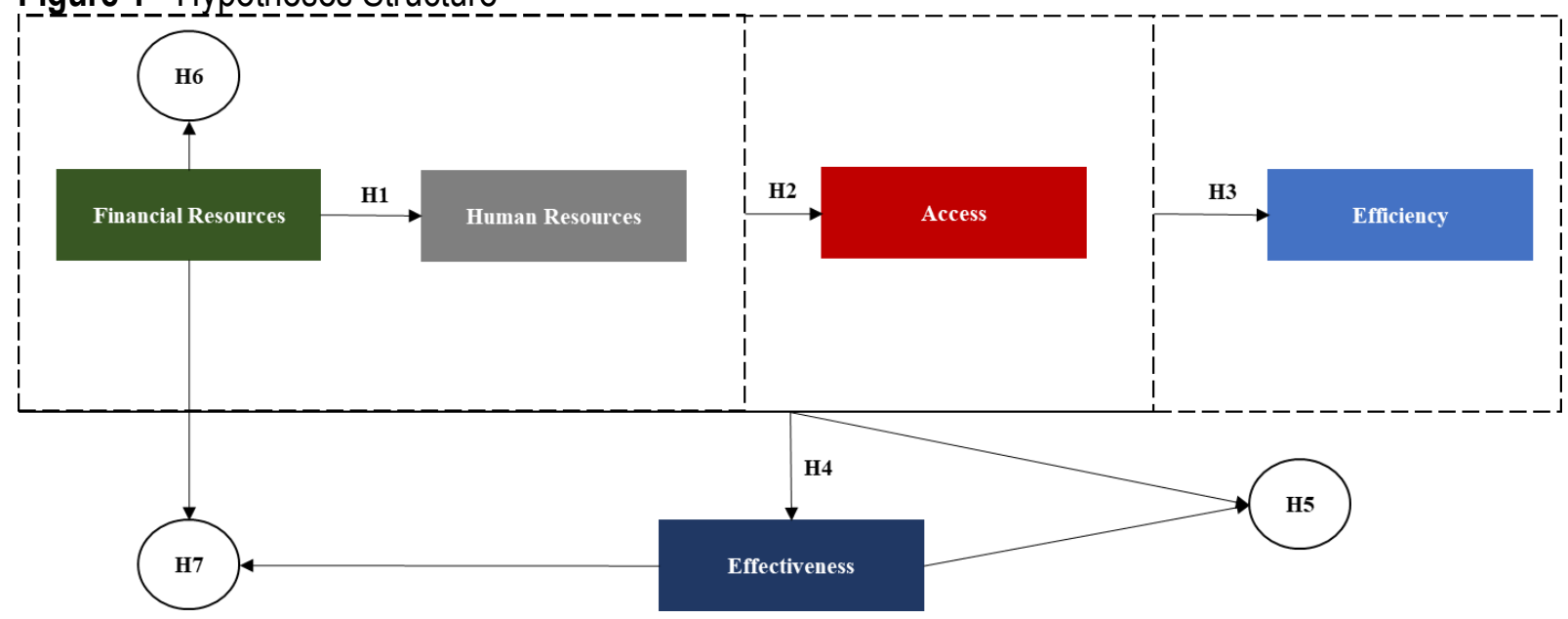

Source: Created by the authors.

\section{METHODS}

\subsection{Data and Samples}

São Paulo State is localized in the Brazilian Southeast and has the main economy of the country, with the highest population, second-highest human development index and second highest number of municipalities (Brazilian Institute of Geography and Statistics [IBGE], 2018). The sample is composed of 645 municipalities in the São Paulo State, and data between 2009 and 2014, 2 periods of mayor's government. The data are 12 indicators collected from Department of Information Technology of SUS (DATASUS) and State System of Data Analysis (SEADE) Foundation (DATASUS, 2018; SEADE, 2018), divided by financial resources, human resources, access, efficiency and effectiveness 
(VIACAVA et al., 2012; WHO, 2013; ALY et al., 2017; ALBUQUERQUE; MARTINS, 2017). After exploring the database, we found 154 outliers, which were excluded from the sample, remaining 3,716 observations.

Table 1- Indicators and dimensions

\begin{tabular}{|l|c|}
\hline \multicolumn{1}{|c|}{ Indicators } & Dimensions \\
\hline $\begin{array}{l}\text { A - Financial transfers from SUS to the municipality, per inhabitant } \\
\text { B - Health expenditures, with own resources, by the municipality, per inhabitant } \\
\text { C- Personal Expenditures divided for the Total Expenditures in Public Health by } \\
\text { the municipality }\end{array}$ & \\
& \\
\hline D - Number of nurses per 1,000 inhabitants & \\
E - Number of physicians per 1,000 inhabitants & Human resources \\
\hline F - Percentual of Bolsa Familia Program Coverage & \\
G - Percentual of Immunization Coverage & Access \\
\hline H - Cytopathologic exams Rate & Efficiency \\
I - Mammography exams Rate & Effectiveness \\
\hline J - Percentual of Normal Births & \\
K - Percentual of Live Births with more than 7 consults & \\
L - Percentual of hospitalization by sensible conditions & \\
\hline
\end{tabular}

Source: Indicators by DATASUS and SEADE Foundation and Dimensions.

The division of the indicators, in dimensions, is based in the municipality's responsibilities, which is the primary care of the public health delivered services (Viacava et al., 2012; WHO, 2013; Aly et al., 2017; Albuquerque \& Martins, 2017). All the data management process, before the statistical analysis, were realized in the Microsoft Excel software.

\subsection{Variables}

The variables reflected the inputs and outcomes of the public health in the municipalities, with a possible association between them. Therefore, the dependent variables were created using the principal component analysis in the indicators. To analyze the hypothesis, the independent variables are the indicators with a possible effect in the dependent variable.

Human resources $=\beta_{0}+\beta_{A}+\beta_{B}+\beta_{C}+\epsilon$

The first equation shows the possible cause-effect between financial resources invested with the human resources in the public health municipalities. With the regression analysis, we can also observe the difference of the effect in the dependent variable between the independent variables, as expenditures with own resources or not. 
Access $=\beta_{0}+\beta_{A}+\beta_{B}+\beta_{C}+\beta_{D}+\beta_{E}+\epsilon$

In the second equation, we want to see the influence of the resources in the access. Therefore, the regression analysis can show a possible cause-effect between resources and more access to the public health delivered services in the municipalities.

Efficiency $=\beta_{0}+\beta_{A}+\beta_{B}+\beta_{C}+\beta_{D}+\beta_{E}+\beta_{F}+\beta_{G}+\epsilon$

Following, the third equation is adding the access indicators, together to the resources, to analyze the possible impacts in the efficiency.

Effectiveness $=\beta_{0}+\beta_{A}+\beta_{B}+\beta_{C}+\beta_{D}+\beta_{E}+\beta_{F}+\beta_{G}+\beta_{H}+\beta_{I}+\epsilon$

Finally, the last regression analysis evaluates the effects of all the indicators with the effectiveness of the municipal health service.

\subsection{Statistical Analysis}

First, we developed a descriptive study to better understand the indicators distribution on the sample (FÁVERO; BELFIORE, 2017). Second, we ran a correlation analysis to identify the standards between the indicators, through the Pearson correlation (HAIR; BLACK; BABIN; ANDERSON; TATHAM, 2010). After, we executed a principal component regression analysis to verify a possible relationship and causality between resources and access, with efficiency and effectiveness (LI; YOU; ZHANG; ZHENG, 2018; TRAN; KIM; KIM; CHOI; CHOI, 2018). For all the statistical analysis we used the SPSS Software v.25, last version of the program.

To better understand the principal component regression analysis, we used the following steps:

1) To create the dependent variables "human resources", "access", "efficiency" and "effectiveness" we used the technique principal component analysis with the Varimax method (Hair et al., 2010; Fávero \& Belfiore, 2017). With the PCA realized, we had just one dependent variable for all the equations (Tu, Kramer \& Leec, 2012). Thus, for the dimensions "human resources", "access", "efficiency" and "effectiveness" we created a "new" factor to represent the concept (FÁVERO; BELFIORE, 2017).

2) After, with dependent variables created, we ran a regression analysis for the 4 hypotheses (TRAN et al., 2018). All the independent variables in the 4 equations did not pass for the component analysis. In the end, our 4 equations had a standard form, as follows: "Component created 
(dep.v) $=$ Pure indicators (indep.v)". In the multiple linear regression analysis, we applied the insert technique with the following statistics: the setting model, $R^{2}$, adjusted $R^{2}$, collinearity diagnostic, the Dursin-Watson technique to residuals, diagnostic per case (-3 and 3 ) and confidence interval of $95 \%$ (Hair et al., 2010).

\section{RESULTS}

\subsection{Health Inequality In The Brazilian Municipalities (Hypothesis 5)}

As we can remark (Table 2), the municipalities in Brazil are heterogeneous on aspects linked with financial and human resources, access and effectiveness. The standards deviations of most parts of the indicators have high values: financial indicators (72.503 and 236.103), human resources (0.513 and 1.848), access (20.035 and 16.926) and effectiveness (15.099).

Table 2 - Descriptive Statistics

\begin{tabular}{|c|c|c|c|r|}
\hline Indicators & Min. & Max. & Mean & Std. Deviation \\
\hline T.SUS p.hab. & 24.870 & 523.540 & 139.641 & 72.503 \\
\hline H.cost p.hab (own) & 88.950 & 2032.300 & 452.143 & 236.103 \\
\hline Personal cost (\%) & 2.300 & 83.610 & 47.002 & 13.193 \\
\hline Nurses x 1000 & 0.004 & 5.859 & 0.880 & 0.513 \\
\hline Physician x 1000 & 0.007 & 15.473 & 2.938 & 1.848 \\
\hline PBF coverage (\%) & 2.130 & 100.000 & 71.528 & 20.035 \\
\hline Immunization coverage (\%) & 38.520 & 186.870 & 83.357 & 16.926 \\
\hline Cytopathologic exam rate & 0.010 & 1.890 & 0.653 & 0.263 \\
\hline Mammography rate & 0.010 & 2.010 & 0.374 & 0.275 \\
\hline Normal births (\%) & 0.920 & 83.930 & 32.403 & 15.099 \\
\hline Live births 7+ consult. & 26.520 & 100.000 & 78.455 & 10.303 \\
\hline Hosp. by sensible cond (\%) & 5.410 & 71.050 & 27.410 & 9.280 \\
\hline
\end{tabular}

Source: Created by the authors.

We can also point out the good means of some human resources (2.938), higher than United Kingdom in 2016 (MOBERLY, 2017), access (71.528 and 83.357) and effectiveness indicators (78.455). However, other effectiveness indicators had low means, as the percentage of normal births (32.403), lower than recommended by WHO (WHO, 2015), and hospitalization by sensible conditions (27.410). 
Therefore, according to the discussion above, we can support the hypothesis 5 showing the different levels on mean and standard deviation in the Brazilian municipalities (Calvo et al., 2016; Ribeiro et al., 2018).

\subsection{Dependency and capacity of the Brazilian municipalities (Hypotheses 6 and 7)}

There is a high positive significant correlation between financial indicators $(0.389)$, human resources (0.379), efficiency indicators (0.309), financial and human resources indicators (0.368 and $0.366)$, financial and access indicators (0.271), financial and efficiency indicators $(0.234,0.340$ and 0.363), and human resources and efficiency indicators (0.300). On the other side, there is a high negative significant correlation between effectiveness indicators (-320), and efficiency and effectiveness indicators $(-0,211)$.

Table 3 - Correlation Matrix

\begin{tabular}{|c|c|c|c|c|c|c|c|c|c|c|c|c|}
\hline & $A$ & $B$ & $C$ & $D$ & $E$ & $F$ & G & $H$ & $I$ & $J$ & $K$ & $L$ \\
\hline$A$ & 1 & & & & & & & & & & & \\
\hline$B$ & $.398^{* *}$ & 1 & & & & & & & & & & \\
\hline C & $\begin{array}{r}- \\
.184^{* *}\end{array}$ & $.127^{* *}$ & 1 & & & & & & & & & \\
\hline$D$ & $.368^{* *}$ & $.366^{* *}$ & .000 & 1 & & & & & & & & \\
\hline$E$ & $.093^{* *}$ & $\begin{array}{r}- \\
.043^{* *}\end{array}$ & $\begin{array}{r}- \\
.136^{* *}\end{array}$ & $.379^{* *}$ & 1 & & & & & & & \\
\hline$F$ & $.164^{* *}$ & $.182^{* *}$ & .008 & $.138^{* *}$ & $\begin{array}{r}- \\
.097^{* *}\end{array}$ & 1 & & & & & & \\
\hline$G$ & $.271^{* *}$ & $.298^{* *}$ & -.009 & $.150^{* *}$ & $\begin{array}{c}- \\
.093^{* *}\end{array}$ & $.129^{* *}$ & 1 & & & & & \\
\hline$H$ & $.192^{* *}$ & $.234^{* *}$ & .017 & $.190^{* *}$ & $\begin{array}{r}- \\
.116^{* *}\end{array}$ & $.151^{* *}$ & $.100^{* *}$ & 1 & & & & \\
\hline I & $.340^{* *}$ & $.363^{* *}$ & .028 & $.300^{* *}$ & -.028 & $.172^{* *}$ & $.249^{* * *}$ & $.309^{* *}$ & 1 & & & \\
\hline$J$ & $.133^{* *}$ & $\begin{array}{r}- \\
.179^{* *}\end{array}$ & $-.040^{*}$ & $\begin{array}{r}- \\
.150^{* *}\end{array}$ & $\begin{array}{r}- \\
.148^{* *}\end{array}$ & $\begin{array}{c}- \\
.105^{* *}\end{array}$ & $\begin{array}{r}- \\
.095^{* *}\end{array}$ & $.051^{* *}$ & $\begin{array}{r}- \\
.211^{* *}\end{array}$ & 1 & & \\
\hline$K$ & $.111^{* *}$ & $.079^{* *}$ & $\begin{array}{r}- \\
.066^{* *}\end{array}$ & $.100^{* *}$ & $.145^{* *}$ & $.063^{* *}$ & $.072^{* *}$ & $.180^{* *}$ & $.142^{* *}$ & $\begin{array}{r}- \\
.320^{* *}\end{array}$ & 1 & \\
\hline$L$ & $\begin{array}{c}- \\
.078^{* *}\end{array}$ & $\begin{array}{c}- \\
.076^{* *}\end{array}$ & $\begin{array}{c}- \\
.044^{* *}\end{array}$ & .022 & .011 & -.001 & -.010 & .024 & -.006 & $\begin{array}{r}- \\
.133^{* *}\end{array}$ & .024 & 1 \\
\hline
\end{tabular}

Source: Created by the authors. 
Looking deeper on these correlations, we can highlight 2 main points:

1) The high positive correlation between the transferred resources, not own resources, with human resources, access, and efficiency, indicates a possible dependence of the municipalities to execute the public health policies.

2) The high negative correlation among the normal births with mammography rate and live births (more than 7 appointments) can show a tendency of richer municipalities spending more money with medical procedures, as for example the cesarean procedures. The high positive correlation between mammography rate and financial indicators corroborates with the tendency.

Thereby, we can go back to the hypothesis 6 and 7 about two propensities: the municipalities depend on the resources transferred from the national health system (Barros \& Lima, 2015), and municipalities with more financial power tend to expend more resources with medical procedures than the necessary (Paschoalotto et al., 2018).

\subsection{Financial resources, Human resources, Access, Efficiency and Effectiveness (Hypotheses 1,}

\section{$2,3$ and 4$)$}

The first point to analyze (Table 4) is about the $R^{2}$ and Adjusted $R^{2}$. In the 4 models, we can observe a low value of both statistics $(0.088,0.162$ and $0.161,0.231$ and $0.230,0.086$ and 0.083$)$, which could report an incapacity of the models in explaining the dependent variables. But, as we are dealing with macro indicators and component principal analysis, it is acceptable to have low $R^{2}$ (Allan, Mooney \& Ling, 2018).

Table 4 - Standardized Coefficients (Beta) of the 4 equations

\begin{tabular}{|ccccc|}
\hline Variables & H1 & H2 & H3 & H4 \\
T.SUS p.hab. & $0.222^{* * *}$ & $0.179^{* * *}$ & $0.164^{* * *}$ & 0.000 \\
H.cost p.hab (own) & $0.113^{* * *}$ & $0.198^{* * *}$ & $0.182^{* * *}$ & $0.055^{* *}$ \\
Personal cost (\%) & $-0.055^{* *}$ & -0.180 & 0.013 & -0.010 \\
Nurses x 1000 & - & $0.123^{* * *}$ & $0.216^{* * *}$ & -0.013 \\
Physicians x 1000 & - & $-0.184^{* * *}$ & $-0.163^{* * *}$ & $0.197^{* * *}$ \\
PBF coverage (\%) & - & - & $0.086^{* * *}$ & $0.071^{* * *}$ \\
Immunization coverage (\%) & - & - & $0.059^{* * *}$ & $0.046^{* *}$ \\
Cytopathologic exam rate & - & - & - & 0.023 \\
Mammographies rate & - & - & - & $0.162^{* * *}$ \\
\hline Number of observations & 3,716 & 3,716 & 3,716 & 3,716 \\
$R^{2}$ & 0.088 & 0.162 & 0.231 & 0.086 \\
Adjusted $R^{2}$ & 0.088 & 0.161 & 0.230 & 0.083 \\
VIF & 1.273 & 1.363 & 1.407 & 1.450
\end{tabular}




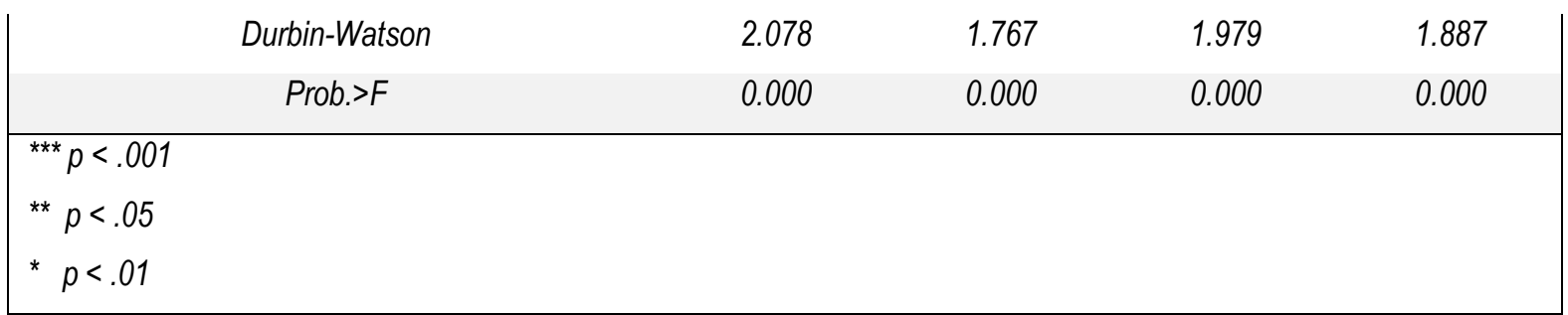

Source: Created by the authors.

The first model, which test hypothesis 1 , has a low $R^{2}$ and adjusted $R^{2}(0.088)$. The low result shows the incapacity of the financial indicators explain human resources in the Brazilian municipalities.

Thus, hypothesis 1 is denied: More financial resources cannot provide more human resources in the Brazilian National Health System (HJORTDBERG; MWIKISA, 2002; CORREIA; DUSSAULT; PONTES, 2015). To finish the discussion of the first model, even with a low capacity of explaining the human resources dependent variable, we can point out the displaced resources to the municipalities (0.222) has more impact in human resources than in the own municipality resources (0.113).

In the second model, to test hypothesis 2 , we can observe a higher $\mathrm{R}^{2}$ and Adjusted $\mathrm{R}^{2}$ than the first model (0.162 and 0.161). About the standardized coefficients (Beta), the results show closest Betas between transferred and own financial resources ( 0.179 and 0.198$)$, a capacity of better explaining the access to the health services with more nurses $(0.123)$, but an inverse relationship with the physicians $(-0,184)$. Therefore, about access, financial resources can better explain human resources.

So, the hypothesis 2 is supported but with reservations: More financial and human resources can provide more access to the population in the Brazilian National Health System, with exception of the physician's indicator (SANTOS; FRANCISCO; GONÇALVES, 2016; PASCHOALOTTO et al., 2018).

Following, the third model, testing hypothesis 3 , has the best explanation model, with better $R^{2}(0.231)$ and adjusted $R^{2}(0.230)$. As we saw in the model 2 , nurses also have an important capacity of better explain the efficiency (0.216), in contrast with the physician's independent variable, which decreases the model's capacity of explaining $(-0,163)$. The financial resources indicators expound a good capacity with the model $(0.164$ and 0.182$)$, but this time with less power than human resources. The access indicators have not helped to have a better model, with modest coefficients (0.086 and 0.059). 
In the end, as the second model, we support the hypothesis with reservations: More resources can provide more efficiency to the Brazilian National Health System, excluding access and physician's indicators (WU; WANG; ZHANG, 2015, PASCHOALOTTO et al., 2018).

Finally, the last model tested the hypothesis 4, and it was denied: More resources, access, and efficiency cannot provide more effectiveness to the Brazilian National Health System (Simba, Mukose \& Bazeyo, 2014). The $R^{2}$ and adjusted $R^{2}$ were the worst between the 4 models ( 0.086 and 0.083), and all the indicators, with exception of "Physician's Rate" (0.197) and "Mammography rate" (0.162), had been a low capacity to expound the effectiveness model.

\section{CONCLUSION}

Therefore, the research has 4 principal findings. First, there is no direct relation between increasing the financial resources and having a more effectiveness public health system in the Brazilian municipalities, as we saw from the low values of $R^{2}$ and adjusted $R^{2}$ in the models and low correlation between the indicators (SIMBA; MUKOSE; BAZEYO, 2014, PASCHOALOTTO et al., 2018).

Second, financial and human resources have more impact on access and efficiency than effectiveness, except for the number of physicians (SANTOS; FRANCISCO; GONÇALVES, 2016). Thereby, it's important to highlight the nurse's action in the SUS. The nurses have a strong impact on primary care, and we can observe through of the results, in access as well as efficiency (TURCI; LIMACOSTA; MACINKO, 2015).

After, we observed a high inequality between the municipalities in the São Paulo State among financial resources, access and, effectiveness (RIBEIRO et al., 2018). One of the causes could be the dependence of the municipalities from the transferred resources (Barros \& Lima, 2015) and the culture of doing medical procedures (spending more resources) instead of following the WHO orientations (PASCHOALOTTO et al., 2018), as higher level of normal births against lower level of cesarean births (WHO, 2015).

Fourth and last, when we are using the "principal components" as a dependent variable, it is not difficult to find lower values for $R^{2}$ and adjusted $R^{2}$, because of your "representative" value and not being a direct indicator (ALLAN; MOONEY; LING, 2018, Li et al., 2018). The method corroborates with the attempt of creating studies about efficiency and effectiveness in a public health system (WORLD BANK, 2018).

The limitations of the study involve historical data series, missing data, indicators' discontinuation, sample, a different type of regression and macrolevel analyses. In Brazil, we have problems with the historical data series, as missing, the quality and discontinuation of the data, mainly in 
the municipalities (ALBUQUERQUE; MARTINS, 2017). Another point is the restrict sample, about the municipalities, years and types of indicators. We have used the municipalities of one Brazilian state due to be the most organized state and with more longitudinal data, with the SEADE Foundation (SEADE, 2018), and we did not use another indicator about equipment, access, efficiency, and effectiveness because of the missing data during the time series. Finally, the method utilized, principal component regression analysis, reduces the explication capacity of the model, because of the macro level analyses (ALLAN; MOONEY; LING, 2018).

To futures studies would be interesting to increase the number and time series of the indicators to represent the dimensions addressed in the study, as well as to add new dimensions and possibilities about explaining the dependent variable (VIACAVA et al., 2012; WHO, 2013; ALY et al., 2017; ALBUQUERQUE; MARTINS, 2017). Besides, testing a new methodology with the linear regression analyses, using the insert technique and in a micro level, could generate more significant and explicate results (LI et al., 2018; TRAN et al., 2018). And, the possibility of comparing different municipalities in the Brazilian states and other countries, to discover new findings to the academic world (ANDRADE et al., 2015).

In the end, we could answer the question: "Could more resources and access impact the efficiency and effectiveness in the municipalities of a Public Health System?". A: Yes, but with no direct and strong relationship between the resources and access, with efficiency and effectiveness, and with less impact in effectiveness than efficiency.

\section{REFERENCES}

ALBUQUERQUE, C.; MARTINS, M. Performance indicators in the Unified Health System: an assessment of advances and gaps. Saúde em Debate, 41(SPE), p.118-137, 2017. doi: http://dx.doi.org/10.1590/0103-11042017s10.

ALLAN, C.; MOONEY, J. D.; LING, J. Social deprivation as a marker for alcohol harms, and implications for local harm reduction policies in England: an ecological study. The Lancet, n.392, v.2, S15. 2018. doi: https://doi.org/10.1016/S0140-6736(18)32098-1

ALY, C. M. C.; REIS, A. T. D.; CARNEIRO, S. A. M. The Unified Health System in a historical series of indicators: a national perspective for action. Saúde em Debate, n. 41, v.113, p. 500-512, 2017.doi: http://dx.doi.org/10.1590/0103-1104201711312

ANDRADE, L. O. M.; PELLEGRINI FILHO, A.; SOLAR, O.; RÍGOLI, F.; SALAZAR, L. M.; SERRATE, P. C. F., ... ; ATUN, R. Social determinants of health, universal health coverage, and sustainable development: case studies from Latin American countries. The Lancet, n. 385, v. 9975, p. 1343-1351, 2015. doi: https://doi.org/10.1016/S0140-6736(14)61494-X 
BARROS, D. M.; LIMA, L. D. Public budget, region and funding in health care: oil revenues and inequalities between municipalities. Ciência \& Saúde Coletiva, v. 20, n.10, p. 2973-2984, 2015. doi: https://doi.org/10.1590/1413-812320152010.00722015

IBGE. Brazilian Institute of Geography and Statistics. Brazilian demographic census of 2010. Retrieved on March 10, 2019, from: https://cidades.ibge.gov.br/brasil/sp

CALVO, M. C. M.; LACERDA, J. T. D.; COLUSSI, C. F.; SCHNEIDER, I. J. C.; ROCHA, T. A. H. Municipalities Stratification for Health Performance Evaluation. Epidemiologia e Serviços de Saúde, n. 25, v. 4, p. 767-776, 2016. doi: https://doi.org/10.5123/S1679-49742016000400010

CARRER, A.; TOSO, B. R. G. D. O.; GUIMARÃES, A. T. B.; CONTERNO, J. R.; MINOSSO, K. C. Effectiveness of the Family Health Strategy in units with, and without, the Mais Médicos (More Doctors) Program in a municipality in the west of Paraná state, Brazil. Ciencia \& saude coletiva, n. 21, v.9, p. 2849-2860, 2016. doi: http://dx.doi.org/10.1590/1413-81232015219.16212016

CORREIA, T.;DUSSAULT, G.; PONTES, C. The impact of the financial crisis on human resources for health policies in three southern-Europe countries. Health Policy, n. 119, p.1600-1605, 2015. doi: http://dx.doi.org/10.1016/j.healthpol.2015.08.009

DATASUS. Department of Information Technology of SUS. (2018). Historical series referring to public health in Brazil. Retrieved on March 19, 2019, from: http://datasus.saude.gov.br

FÁVERO, L. P.; BELFIORE, F. Manual de Análise de Dados: Estatística e Modelagem Multivariada com Excel, SPSS e Stata. Rio de Janeiro, Elsevier Brasil, 2017.

FRIEBEL, R.; MOLLOY, A.; LEATHERMAN, S.; DIXON, J.; BAUHOFF, S.; CHALKIDOU, K. (2018). Achieving high-quality universal health coverage: a perspective from the National Health Service in England. BMJ global health, n. 3, v.6, 2018. e000944. doi: http://dx.doiorg.ez67.periodicos.capes.gov.br/10.1136/bmjgh-2018-000944

HAIR JR., J.F.; ANDERSON, R. E.; BABIN, B. J.; BLACK, W. C. Multivariate Data Analysis: A global perspective. New Jersey, Pearson, 2010.

HJORTSBERG, C.A.; MWIKISA, C.N. Cost of access to health services in Zambia. Health Policy and Planning, n. 17, v.1, p. 71-77, 2002. doi: https://doi.org/10.1093/heapol/17.1.71

LAGO, F. P.; MOSCOSO, N. S.; ELORZA, M. E.; RIPARI, N. V. (2012). Descentralización y equidad: el gasto público en salud en los municipios de la provincia de Buenos Aires. Salud colectiva, n. 8, v.3, p. 263-274, 2012. doi: http://www.scielo.org.ar/scielo.php?script=sci_arttext\&pid=S185182652012000400004

LI, H.; YOU, S.; ZHANG, H.; ZHENG, W.; LEE, W. L.; YE, T.; ZOU, L. Analyzing the impact of heating emissions on air quality index based on principal component regression. Journal of cleaner production, n. 171, p.1577-1592, 2018. doi: https://doi.org/10.1016/j.jclepro.2017.10.106

MADUREIRA-LIMA, J.; REEVES, A.; CLAIR, A.; STUCKLER, D. The Great Recession and inequalities in access to health care: a study of unemployment and unmet medical need in Europe in the economic crisis. International journal of epidemiology, n. 47, v.1, p. 58-68, 2018. doi: 10.1093/ije/dyx193 
MCPAKE, B.; WITTER, S.; ENSOR, T.; FUSTUKIAN, S.; NEWLANDS, D.; MARTINEAU, T.; CHIRWA, $Y$. Removing financial barriers to access reproductive, maternal and newborn health services: the challenges and policy implications for human resources for health. Human Resources for Health, $\mathrm{n}$. 11, v.1, p.46, 2013. doi: https://doi.org/10.1186/1478-4491-11-46

MENDES, A.; CARNUT, L.; GUERRA, L.D. DA S. Reflexões acerca do financiamento federal da Atenção Básica no Sistema Único de Saúde. Saúde em Debate, n. 42(Special 1), p. 224-243, 2018. doi: http://dx.doi.org/10.1590/0103-11042018s115.

MOBERLY, Tom. UK has fewer doctors per person than most other OECD countries. BMJ, 357, j2940, 2017. doi: https://doi.org/10.1136/bmj.j2940

NARASIMHAN, V.; BROWN, H.; PABLOS-MENDEZ, A.; ADAMS, O.; DUSSAULT, G.; ELZINGA, G., ...; SEWANKAMBO, N. Responding to the global human resources crisis. The Lancet, n. 363, v. 9419, p. 1469-1472, 2004. doi: 10.1016/S0140-6736(04)16108-4

PALMER, N.; MUELLER, D. H.; GILSON, L.; MILLS, A.; HAINES, A. Health financing to promote access in low income settings-how much do we know?. The Lancet, n. 364, v. 9442, p. 1365-1370, 2004. doi: 10.1016/S0140-6736(04)17195-X

PASCHOALOTTO, M. A. C.; PASSADOR, J. L.; OLIVEIRA, L. R. D.; LOPES, J. E. F.; DANTAS, M. K.; PASSADOR, C. S. A regionalização do SUS: proposta de avaliação de desempenho dos Departamentos Regionais de Saúde do estado de São Paulo. Saúde e Sociedade, n. 27, p. 80-93, 2018. doi: http://dx.doi.org/10.1590/s0104-12902018170095.

PENNESTRÌ, F. L'essenziale a tutti. I nuovi livelli di assistenza fra sostenibilità ed equità. Notizie di POLITEIA, n. 33, v. 128, p. 60-73, 2017.

RIBEIRO, J. M.; MOREIRA, M. R.; OUVERNEY, A. M.; PINTO, L. F.; SILVA, C. M. F. P. D. Federalism and health policy in Brazil: institutional features and regional inequalities. Ciencia \& saude coletiva, $\mathrm{n}$. 23, v. 6, p.1777-1789, 2018. doi: https://doi.org/10.1590/1413-81232018236.07932018

SANTOS NETO, J.A.; PEREIRA, A. C.; PARANHOS, L. R. Analysis of the Unified Health System funding and expenditure in the municipalities of the "Rota dos Bandeirantes" health region, State of São Paulo, Brazil. Ciencia \& saude coletiva, n. 22, v. 4, p. 1269-1280, 2017. doi: https://doi.org/10.1590/1413-81232017224.28452016

SANTOS, L.M., FRANCISCO, J. R. S. \& GONÇALVES, M.A. Controle na alocação de recursos na saúde pública: uma análise nas microrregiões do sudeste brasileiro. Administração Pública e Gestão Social, n. 8, v. 2, p. 119-129, 2016. doi: https://doi.org/10.21118/apgs.v1i2.581

SIMBA, D.; MUKOSE, A.; BEZEYO, W. Institutional capacity for health systems research in East and Central African Schools of Public Health: strengthening human and financial resources. Health Research Policy and Systems, n. 12, v. 1, p. 23, 2014. doi: 10.1186/1478-4505-12-23

STATE SYSTEM OF DATA ANALYSIS FOUNDATION. SEADE Foundation. (2018). Historical series referring to public health in the State of São Paulo. São Paulo/SP. Retrieved on March 09, 2019, from: http://www.seade.gov.br/ 
TRAN, H.; KIM, J.; KIM, D.; CHOI, M.; CHOI, M. (2018). Impact of air pollution on cause-specific mortality in Korea: Results from Bayesian Model Averaging and Principle Component Regression approaches. Science of The Total Environment, n. 636, p. 1020-1031, 2018. doi: https://doi.org/10.1016/j.scitotenv.2018.04.273

TU, Y.; KRAMER, N.; LEEC, W. (2012). Addressing the Identification Problem in Age-period-cohort Analysis: A Tutorial on the Use of Partial Least Squares and Principal Components Analysis. Epidemiology, n. 23, v. 4, p. 583-593, 2012. doi: https://doi.org/10.1097/EDE.0b013e31824d57a9

TURCI, M.A.; LIMA-COSTA, M. F.; MACINKO, J. The influence of structural and organizational factors on the performance of primary health care in Belo Horizonte, Minas Gerais State, Brazil, according to nurses and managers. Cadernos de Saúde Pública, n. 31, v. 9, p. 1941-1952, 2015. doi: http://dx.doi.org/10.1590/0102-311X00132114

VERGUET, S.; KIM, J. J.; JAMISON, D. T. Extended Cost-Effectiveness Analysis for Health Policy Assessment: A Tutorial. PharmacoEconomics, n. 34, p. 913-923, 2016. doi:

https://doi.org/10.1007/s40273-016-0414-z

VIACAVA, F.; UGÁ, M. A. D.; PORTO, S.; LAGUARDIA, J.; MOREIRA, R. D. S. Evaluation of performance of health systems: a model for analysis. Ciencia \& saude coletiva, n. 17, v.4, p. 921-934, 2012. doi: http://dx.doi.org/10.1590/S1413-81232012000400014

VODA, A.I.; BOSTAN, I. Public Health Care Financing and the Costs of Cancer Care: A Cross-National Analysis. Cancers, n.10, v.117, 2018. doi: 10.3390/cancers10040117

WORLD BANK. (2018). 30 Anos de SUS: Desafios para Sustentabilidade. Retrieved on March 05, 2019, from:

http://iris.paho.org/xmlui/bitstream/handle/123456789/49663/9789275720448_por.pdf?sequence=1\&isA llowed=y

WORLD HEALTH ORGANIZATION. (WHO). (2013). Evaluation practice handbook. Retrieved on March 05, 2019, from:

https://apps.who.int/iris/bitstream/handle/10665/96311/9789241548687_eng.pdf;jsessionid=DC5DA45F F9EFE434F06C6058A00247FE?sequence=1

WORLD HEALTH ORGANIZATION. WHO. WHO Statement on Caesarean Section Rates. Geneva: 2015.

WORLD HEALTH ORGANIZATION. WHO. World health statistics 2018: monitoring health for the SDGs, sustainable development goals. Geneva: 2018.

WU, S., WANG, C. \& ZANG, G. (2015). Has China's new health care reform improved efficiency at the provincial level? Evidence from a panel data of 31 Chinese provinces. Journal of Asian Public Policy, n. 8, v.1, p.36-55, 2015. http://dx.doi.org/10.1080/17516234.2015.1009399 